\title{
Perbandingan Penggunaan Dua Jenis Ransum terhadap Berat Potong Berat Karkas dan Berat Lemak Abdominal Broiler
}

\author{
Maria Selfiana Pasi ${ }^{\mathrm{a}}$, dan Oktovianus R. Nahak T. B. ${ }^{\mathrm{b}}$ \\ ${ }^{a}$ Fakultas Pertanian, Universitas Timor, Kefamenanu, TTU - NTT, 85613, Indonesia. \\ ${ }^{b}$ Fakultas Pertanian, Universitas Timor, Kefamenanu, TTU - NTT, 85613, Indonesia.
}

\section{Article Info}

\section{Article history:}

Received 10 Mei 2016

Received in revised form 25 Juni 2016

Accepted 27 Juni 2016

\section{Keywords:}

Ransum

Berat Potong Karkas

Lemak Abdonia

Ayam Broiler.

\begin{abstract}
Abstrak
Tujuan penelitian ini adalah untuk membandingkan kualitas ransum buatan dengan ransum komersial terhadap berat pemotongan, bera karkas dan berat lemak abdominal ayam broiler. Penelitian ini menggunakan metode eksperimen dengan melakukan pengujian terhadap perbandingan pada perlakuan ransum buatan dan ransum komersial. Variabel yang diukur pada penelitian ini terdiri dari Berat potong (g/ekor); Berat karkas (g/ekor) dan Berat lemak abdominal (g/ekor). Hasil penelitian menunjukkan bahwa berat potong tertingg ditunjukkan pada perlakuan Ransum komersial 1772,94 g/ekor lebih tinggi dibandingkan ransum buatan 1761,06 g/ekor atau selisih 11,88 g/ekor, Pada berat karkas tertinggi yaitu pada perlakuan ransum komersial 1584,03 gr/ekor lebih tinggi dibandingkan ransum buatan 1573,37 g/ekor atau selisih 10,66 g/ekor, pada berat lemak abdominal tertinggi pada perlakuan ransum komersial 27,37 g/ekor dibandingkan ransum buatan 9,94 g/ekor atau selisih 17,44 g/ekor. Hasil uji t menunjukkan bahwa pada variabel berat potong dan berat karkas menunjukkan tidak berbeda nyata $(\mathrm{p}>0,05)$ antara ransum buatan terhadap ransum komersial atau dengan kata lain kedua perlakuan memiliki kualitas yang sama sedangkan pada variabel lemak abdominal menunjukkan perbedaan nyata $(\mathrm{p}<0,01)$ hal in menunjukkan bahwa ransum buatan menghasilkan lemak lebih sedikit dibanding ransum komersial. Dapat dikatakan bahwa kualitas ransum buatan sama baiknya dengan ransum komersial namun lebih baik pada lemak abdominal.@2016 dipublikasikan oleh JAS.
\end{abstract}

\section{Pendahuluan}

Pencapaian swasembada daging merupakan salah satu program pemerintah dalam rangka mencukupi kebutuhan pangan nasional berkualitas sehingga tercipta stabilitas dan kemandirian bangsa. Upaya swasembada daging tentunya akan tercapai bilamana semua aspek terkait pencapaian produktivitas ternak dapat dicapai dengan baik. Salah satu ternak yang memberikan sumbangan terbesar saat ini terhadap pemenuhan kebutuhan protein hewani adalah ternak ayam broiler.

Ayam broiler merupakan jenis ras unggulan persilangan dari bangsabangsa ayam yang memiliki daya produktivitas tinggi, terutama dalam memproduksi daging ayam (Anita dan Widagdo, 2011). Laju Pertumbuhan ternak ayam broiler sangat dipengaruhi oleh beberapa faktor, salah satunya adalah kualitas dan kuantitas nutrisi ransum yang memadai.

Ransum adalah pakan jadi yang siap diberikan kepada ternak yang disusun dari berbagai jenis bahan pakan yang sudah dihitung (dikalkulasikan) berdasarkan kebutuhannya. Ransum merupakan salah satu faktor yang menentukan keberhasilan usaha ayam broiler. Hal ini karena biaya ransum merupakan biaya terbesar dari biaya produksi yaitu bisa mencapai sekitar 70\%.Oleh karena itu, pemilihan ransum harus tepat dan sesuai dengan kebutuhan ayam broiler (Supriyadi, 2011).

Menurut (Anita dan Widagdo, 2011), karkas adalah bagian tubuh ternak yang telah disembelih yang dipotong bagian kaki, leher kemudian seluruh is perut (usus dan ampela) dikeluarkan.

Ayam broiler untuk saat ini memiliki kandungan lemak yang cukup tingg namun dari hasil seleksi secara intensif ternyata menyebabkan peningkatan kandungan lemak dalam karkas mencapai $18 \%$, sehingga masalah tersebu menjadi perhatian khusus bagi para konsumen dan produsen ternak. Ayam broiler termasuk ternak yang mempunyai tingkat koefisiensi yang tinggi dalam mengkonversi pakan menjadi daging. Dewasa ini para peternak ayam broile masih menggunakan ransum komersial yang dibeli dengan harga yang cukup mahal namun kualitas nutrisi yang tidak efisien sehingga memberikan dampak negatif bagi para peternak.

Penggunaan bahan pakan lokal seperti tepung gaplek, dedak padi, tepung ikan, tepung daun turi dan ditambah dengan bahan pakan pendukung lainnya menjadi bahan dasar lokal yang diolah menjadi ransum diharapkan membawa dampak yang positif terhadap peningkatan bobot badan ayam broiler sehingga penelitian ini bertujuan untuk membandingkan kualitas ransum yang dibua sendiri dengan ransum komersial terhadap berat pemotongan, berat karkas dan berat lemak abdominal ayam broiler.

\section{Metode}

Penelitian ini dilaksanakan pada kandang unggas Program Stud Peternakan, Fakultas Pertanian, Universitas Timor yang berlangsung selama 5 minggu, dari bulan Maret sampai pertengahan April 2016. Ternak yang dipaka dalam penelitian ini adalah Day Old Chick (DOC) strain CP 707 produksi PT Charoen Phockpan sebanyak 80 ekor, yang dibeli pada poultry shop yang ada di kota Kefamenanu. Alat yang digunakan adalah timbangan duduk kapasitas $\mathrm{kg}$ untuk menimbang ransum, timbangan analitik kapasitas $2 \mathrm{~kg}$ untuk menimbang berat potong, karkas dan lemak abdominal. Alat pencetakan ransum berbentuk pellet, kandang tipe lantai dengan model lorong yang terdir dari 16 petak. Tiap petak kandang berukuran 1 x $0,5 \mathrm{~m}$. Sekat antara petak berukuran $50 \mathrm{~cm}$ dari permukaan lantai, tiap petak kandang dilengkapi tempat makan dan minum serta pemanas menggunakan lampu pinjar 100 watt. Alat lainya yang digunakan adalah oven, almunium foil, pisau, baskom, terpal Bahan yang digunakan dalam penelitian ini terdiri ransum komersial yaitu BR1 untuk ternak pada fase starter dan BR2 untuk ternak pada fase finisher, sedangkan ransum buatan menggunakan bahan berupa tepung gaplek, jagung giling, dedak padi, tepung daun turi, kunyit, molases, probiotik, minyak kelapa dan tepung kanji. Vaksin yang akan digunakan terdiri dari 2 jenis vaksin yaitu ND Lasota dan ND IB. ND Lasota diberikan pada umur 4 hari dengan sistem tetes pada mata dan ND IB pada umur 2 minggu dengan dicampurkan pada air minum.

\begin{tabular}{|c|c|c|c|}
\hline No & Nutrisi & Periode starter & Periode finisher \\
\hline 1 & Protein $(\%)$ & $22,00 \%$ & $20,00 \%$ \\
\hline 2 & Gross energy ( $\mathrm{kkal} / \mathrm{kg}$ ) & $2800-3200$ & $2900-3200$ \\
\hline 3 & Kalsium ( \% ) & 1,00 & 0,90 \\
\hline 4 & Fosfor $(\%)$ & 0,45 & 0,35 \\
\hline
\end{tabular}

Sumber : Anita dan Widagdo (2011)

Penelitian ini menggunakan model experimen dimana perlakuan yang diuji terdiri dari ransum buatan (X1) dan ransum komersial (X2). Setiap perlakuan akan diuji pada 8 petak kandang dimana setiap petak terdiri dari 5 ekor ayam broiler.

Tabel 2. Nilai Nutrisi Bahan Baku Lokal Ransum Buatan

\begin{tabular}{|c|c|c|c|c|c|c|c|}
\hline No & Bahan & $\begin{array}{l}\text { Gross } \\
\text { energy }\end{array}$ & PK & LK & BK & SK & Kalsium \\
\hline 1 & Gaplek & $2.600 \mathrm{kkal}$ & 1,7 & - & & 1,6 & 0,12 \\
\hline 2 & Daun Turi & - & 40,62 & 5,66 & 28,3 & 10,67 & 0,18 \\
\hline 3 & Jagung Kuning & $3.430 \mathrm{kkal}$ & 9,0 & 4,23 & 86,80 & 2,53 & \\
\hline 4 & Dedak & & 10,40 & 8,10 & 88,60 & 10,60 & - \\
\hline 5 & Tepung ikan & & 61,80 & 7,43 & 87,30 & 2,10 & - \\
\hline
\end{tabular}

5 Tepung ikan

Sumber : Wahju (2004)

Pembuatan ransum diawali dengan menyiapkan bahan baku yang telah dibuat dalam bentuk tepung seperti tepung jagung, tepung gaplek, tepung ikan, tepung daun turi, tepung kunyit. Selanjutnya bahan yang ada di campur secara manual sampai terlihat homogen. Campuran bahan diberi larutan molases probiotik dan minyak kelapa. Ransum yang telah dicampur diberi larutan kanji sambil dipercikan air sampai campuran bahan nampak basah bila dikepal. Selanjutnya ransum dicetak dengan menggunakan mesin pelleting dengan ukuran $0,5 \mathrm{~cm}$. Pelet yang telah dicetak kemudian dijemur selama 1 har selanjutnya dimasukan dalam oven dengan suhu $70^{\circ} \mathrm{C}$ selama 2 hari.

Tabel 3. Komposisi Ransum Buatan $100 \mathrm{~kg}$

\begin{tabular}{clc}
\hline No & \multicolumn{1}{c}{ Jenis bahan } & Komposisi $(\mathrm{kg})$ \\
\hline 1 & Tepung gaplek & 25 \\
2 & Jagung giling & 40 \\
3 & Dedak padi & 10 \\
4 & Tepung ikan & 10 \\
5 & Tepung daun turi & 8 \\
6 & Kunyit & 5 \\
7 & Minyak kelapa & 0,5 \\
8 & Molases & 1 \\
9 & Probiotik & 0,5
\end{tabular}

Tipe kandang yang digunakan berupa kandang lantai dengan model lorong. Sekat antar petak kandang dibuat dari batang kayu dimana jumlah petak kandang dibuat sebanyak 16 petak, setiap petak dibuat dengan ukuran 1x 0,5 m dan alas kandang berupa sekam padi dengan ketebalan $10 \mathrm{~cm}$ dari lantai. Setiap petak kandang disiapkan tempat makan dan minum masing-masing 1 buah. 
Pada tahap awal ternak ayam broiler di beri larutan air gula untuk mengurangi dampak stres selama perjalanan. Ayam broiler ditempatkan pada 2 petak kandang kumunal dimana setiap petak kandang komunal berisi 40 ekor. Selama 5 hari ternak sudah mulai dibiasakan dengan ransum yang akan diuji selanjutnya pada hari ke 6 dipindahkan ke dalam setiap petak kandang dimana setiap petak diisi ayam broiler sebanyak 5 ekor.

Ransum yang diuji dalam penelitian ini berupa ransum buatan dan ransum komersial. Pemberian ransum pada minggu pertama dan kedua sebanyak 300 gram/petak untuk setiap jenis ransum, selanjutnya pada minggu ke 3 diberikan 500 gram/petak, minggu ke 4 diberikan 800 gram/petak dan minggu ke 5 diberikan $1000 \mathrm{gr} /$ petak.

Data berat potong, berat karkas dan berat lemak abdominal diambil pada saat ternak berusia 35 hari. Sebelum dipotong terlebih dahulu ternak dipuasakan selama 12 jam selanjutnya ditimbang untuk mendapatkan data berat potong. Setelah ditimbang ternak disembelih kemudian dikeluarkan darah, persendian tulang kaki, kepala, bulu dan organ internal kemudian ditimbang untuk mendapatkan data berat karkas. Lemak abdominal diperoleh dengan memisahkan bagian lemak yang ada di bawah perut selanjutnya ditimbang sebagai data berat lemak abdominal.

Variabel yang diamati dalam penelitian ini adalah menguji kualitas ransum dengan memperhatikan penampilan ayam Broiler sebagai berikut :

1. Berat potong (gr)

Berat potong di peroleh dari hasil penimbangan ternak dimana sebelum disembelih ternak dipuasakan selama 12 jam.

2. Berat karkas (gr)

Berat karkas diperoleh dari hasil penimbangan bagian tubuh ternak setelah disembelih dan dikeluarkan bulu, darah, kepala, kaki, jeroan.

3. Berat lemak abdominal (gr)

Berat lemak abdominal adalah hasil penimbangan lemak yang deposisi kelebihan dibagian bawah perut.

Data yang diperoleh dalam penelitian ini dianalisa dengan menggunakan analisa deksriptif yaitu menghitung nilai rata - rata dari masing masing variabel, standar deviasi dan koefisien keragaman dengan formulasi masing-masing sesuai petunjuk (Sugiyono, 2000). Sementara itu untuk membandingkan produktifitas ransum yang dibuat sendiri dengan ransum komersial digunakan uji t (t-test) berdasarkan petunjuk (Soematri dan Muhidin, 2006).

\section{Hasil dan Pembahasan}

\subsection{Gambaran Umum Penelitian}

Ternak yang digunakan dalam penelitian ini adalah Broiler strain CP 707 sebanyak 80 ekor. Keadaan ternak sewaktu tiba yaitu dalam keadaan sehat Pada saat DOC tiba di kandang penelitian, DOC langsung ditimbang untuk mengetahui berat awal. Kemudian DOC dibagi 40 ekor pada perlakuan ransum komersial dan 40 ekor untuk perlakuan ransum buatan dan selanjutnya diberi air gula untuk mencegah keadaan stress selama perjalanan. Setelah 15 menit diberi air gula DOC langsung diberi ransum sesuai perlakuan pemberian ransum

Pada hari pertama sampai pada hari keempat masa preliminary Broiler beradaptasi dengan suhu lingkungan yang baik dan tidak terlihat hambatan apapun pada pertumbuhan Broiler. Pada hari kelima Broiler divaksinasi dengan ND Lasota melalui tetes mata dan melakukan penimbangan kemudian dipindahkan ke kandang perlakuan dan setiap petak diisi dengan 5 ekor Broiler.

Pada minggu pertama penelitian pengambilan data ada seekor Broiler mati yaitu pada perlakuan ransum komersial kandang nomor pertama. Hal in ini diduga Broiler tersedak sekam. Pada saat memasuki minggu ketiga masa penelitian ada beberapa ternak pada perlakuan ransum komersial mengalami penyakit berak kapur (Pullorum). Penyakit ini menular melalui kotoran. Pengendalian ternak tersebut yaitu pergantian litter apabila banyak kotoran dan lembab.

Pada saat Broiler umur 35 hari dipuasakan selama 12 jam untuk mengambil data berat pemotongan. Setelah itu ternak disembelih dan dipisahkan dar kepala, kaki, dan organ internal untuk ditimbang guna mengetahui data berat karkas setelah itu mengambil lemak yang berada dibawa perut dan di timbang untuk mengetahui data berat lemak abdominal.

\subsection{Pengaruh Perlakuan Terhadap Berat Potong (gr)}

Berat potong yang dimaksud dalam penelitian ini adalah berat yang di peroleh setelah ternak dipuasakan selama 12 jam. Hasil perhitungan nilai ratarata berat potong di lihat pada Tabel 4 . Pada tabel tersebut terlihat bahwa ratarata berat potong tertinggi dicapai oleh perlakuan ransum komersial yaitu 1772,94 gram/ekor dan pada perlakuan ransum buatan sebesar 1761.06 gram/ekor atau selisih 11,88 gram

Nilai standar deviasi (SD) dan koevisien keragaman (KK) terendah diperoleh pada perlakuan ransum buatan yaitu masing-masing 12,11 dan 0,68\% sedangkan pada ransum komersial masing-masing 12,67 dan $0,71 \%$. Dari hasi tersebut menunjukkan bahwa kedua jenis ransum ini menghasilkan nilai keragaman yang relatif sama atau dengan kata lain bahwa tidak terdapat perbedaan keragaman baik pada ransum buatan maupun ransum komersial.

Hasil analisis (t-test) menunjukkan bahwa perbedaan berat potong antara kedua perlakuan ini tidak berbeda nyata $(\mathrm{p}>0,05)$. Dengan kata lain kedua perlakuan ini memiliki kualitas yang sama. Hal ini berarti ransum buatan yang diberikan pada ayam Broiler mampu memberikan nilai berat potong sama dengan ransum komersial.

Tabel 4. Rata-rata Berat Potong (gram)

\begin{tabular}{crrrr}
\hline No. Petak & \multicolumn{1}{c}{$\mathrm{X}_{1}$} & \multicolumn{1}{c}{$\mathrm{X}_{2}$} & \multicolumn{1}{c}{$\mathrm{X}_{1}{ }^{2}$} & \multicolumn{1}{c}{$\mathrm{X}_{2}{ }^{2}$} \\
\hline 1 & 1767.33 & 1791.05 & 3123455.3 & 3207860 \\
2 & 1740.22 & 1781.74 & 3028365.7 & 3174597 \\
3 & 1778.09 & 1783.04 & 3161604.1 & 3179232 \\
4 & 1766.31 & 1780.71 & 3119851 & 3170928 \\
5 & 1760.46 & 1766.42 & 3099219.4 & 3120240 \\
6 & 1770.41 & 1764.22 & 3134351.6 & 3112472 \\
7 & 1755.18 & 1757.71 & 3080656.8 & 3089544 \\
8 & 1750.45 & 1758.59 & 3064075 & 3092639 \\
\hline Jumlah & 14088.45 & 14183.48 & 24811578.9 & 25147512 \\
\hline Rataan & 1761.06 & 1772.94 & 3101447.36 & 3143439 \\
\hline SD & 12.11 & 12.672913 & 42593.42551 & 44944.58 \\
\hline KK & 0.69 & 0.71 & 1.37 & 1.43 \\
\hline Keteran
\end{tabular}

Keterangan : $\mathrm{X}_{1}$ : Ransum Buatan; $\mathrm{X}_{2}$ : Ransum Komersial

Kemampuan ransum buatan dalam mengimbangi ransum komersial dari aspek berat potong disebabkan karena tingginya nilai nutrisi yang terdapat pada ransum buatan. Hal ini sesuai dengan (Fadilah, 2013) mengatakan pakan dengan energi yang tinggi akan memerlukan asam amino dan protein yang tinggi pula. Tujuannya mengatur kandungan lemak dan kualitas karkas ayam sehingga meningkatkan berat pemotongan yang tinggi.

\subsection{Pengaruh Perlakuan Terhadap Berat Karkas (gr)}

Berat karkas yang dimaksud dalam penelitian ini adalah berat yang diperoleh dari hasil penimbangan bagian tubuh ternak setelah disembelih dan dikeluarkan darah, kepala, kaki, jeroan. Hasil perhitungan nilai rata-rata berat karkas dari ternak percobaan masing-masing perlakuan terlihat pada Tabel 5.

Tabel 5. Nilai Rata-rata Berat Karkas (gram)

\begin{tabular}{crrrr}
\hline No. Petak & \multicolumn{1}{c}{$\mathrm{X}_{1}$} & \multicolumn{1}{c}{$\mathrm{X}_{2}$} & \multicolumn{1}{c}{$\mathrm{X}_{1}{ }^{2}$} & \multicolumn{1}{c}{$\mathrm{X}_{2}{ }^{2}$} \\
\hline 1 & 1588.28 & 1583.36 & 2522633 & 2507029 \\
2 & 1569.88 & 1579.64 & 2464523 & 2495263 \\
3 & 1578 & 1575.24 & 2490084 & 2481381 \\
4 & 1580.02 & 1596.73 & 2496463 & 2549547 \\
5 & 1573.37 & 1582.64 & 2475493 & 2504749 \\
6 & 1559.29 & 1581.94 & 2431385 & 2502534 \\
7 & 1567.43 & 1589.94 & 2456837 & 2527909 \\
8 & 1570.69 & 1582.76 & 2467067 & 2505129 \\
Jumlah & 12586.96 & 12672.25 & 19804486 & 20073541 \\
\hline Rataan & 1573.37 & 1584.031 & 2475561 & 2509193 \\
\hline SD & 8.79 & 6.56 & 27670.77 & 20810.58 \\
\hline KK & 0.56 & 0.41 & 1.12 & 0.83 \\
\hline Ken
\end{tabular}

Keterangan : $\mathrm{X}_{1}$ : Ransum Buatan; $\mathrm{X}_{2}$ : Ransum Komersial

Pada tabel di atas menunjukkan rata-rata berat karkas pada perlakuan ransum buatan adalah 1573,37 gram/ekor dan pada perlakuan ransum komesia 1584,03 gram/ekor atau selisih 10,66 gram

Nilai standar deviasi (SD) dan koefisien keragaman (KK) terendah pada berat karkas diperoleh pada ransum komersial masing-masing 6,55 dan 0,41\% sedangkan pada ransum buatan masing-masing 8,79 dan $0,55 \%$. Namun demikian perbedaan nilai SD dan KK antara ransum buatan dan ransum komersial memiliki selisih nilai yang tidak berbeda jauh sehingga dapat dikatakan bahwa pemberian ransum buatan maupun ransum komersial menghasilkan keragaman yang relatif sama pada berat karkas ayam broiler.

Hasil analisis (T-test) menunjukkan bahwa perbedaan berat karkas antara kedua perlakuan ini tidak berbeda nyata $(p>0,05)$. Dengan kata lain kedua perlakuan ini memiliki kualitas yang sama. Hal ini menunjukkan bahwa kualitas ransum buatan mampu mengimbangi ransum komersial dimana menghasilkan berat karkas yang tidak berbeda sehingga dapat dikatakan bahwa ransum buatan yang dikonsumsi sangat efektif untuk diubah menjadi karkas. Hal ini sesuai dengan Wahju, (2004) bahwa apabila dalam pemberian ransum mengandung zat-zat makanan yang dibutuhkan ternak maka akan memberikan nilai karkas yang baik karena efisiensi penggunaan makanan bergantung pada energi pada ransum tersebut.

Selanjutnya (Sudiyono, 2002) mengatakan ayam Broiler yang menghasilkan berat karkas yang tinggi adalah ayam yang dalam masa-masa pertumbuhan. Faktor yang berpengaruh terhadap berat karkas adalah umur, jenis kelamin, berat badan serta kuantitas dan kualitas pakan yang di berikan.

\subsection{Pengaruh Perlakuan Terhadap Berat Lemak Abdominal}

Berat lemak abdominal yang dimaksud dalam penelitian ini adalah deposisi dari kelebihan lemak yang berada di bagian bawah perut ternak ayam Broiler.

Hasil perhitungan nilai rata-rata berat lemak abdominal dari ternak percobaan masing-masing perlakuan terlihat pada Tabel 6. Nilai rata-rata berat lemak tertinggi dicapai oleh ternak yang mendapat perlakuan ransum komersial yaitu 27,37 gram/ekor dan pada perlakuan ransum buatan adalah 9,95 gram/ekor. 
Tabel 6. Nilai Rata-rata Berat Lemak Abdominal (gram)

\begin{tabular}{crrrr}
\hline No. Petak & \multicolumn{1}{c}{$\mathrm{X}_{1}$} & \multicolumn{1}{c}{$\mathrm{X}_{2}$} & \multicolumn{1}{c}{$\mathrm{X}_{1}{ }^{2}$} & \multicolumn{1}{c}{$\mathrm{X}_{2}{ }^{2}$} \\
\hline 1 & 9.87 & 26.71 & 97.42 & 713.42 \\
3 & 9.66 & 27.09 & 93.32 & 733.87 \\
4 & 10.50 & 27.41 & 110.25 & 751.31 \\
5 & 9.80 & 27.48 & 96.04 & 755.15 \\
6 & 9.90 & 27.63 & 98.01 & 763.42 \\
7 & 10.11 & 27.57 & 102.21 & 760.10 \\
8 & 9.83 & 27.56 & 96.63 & 759.55 \\
Jumlah & 9.91 & 27.50 & 98.21 & 756.25 \\
Rataan & 79.58 & 218.95 & 792.08 & 5993.08 \\
\hline SD & 9.95 & 27.37 & 99.01 & 749.13 \\
\hline KK & 0.26 & 0.31 & 5.18 & 17.04 \\
\hline Keter & 2.57 & 1.14 & 5.22 & 2.27 \\
\hline
\end{tabular}

Keterangan : $\mathrm{X}_{1}$ : Ransum Buatan; $\mathrm{X}_{2}$ : Ransum Komersial

Nilai standar deviasi (SD) terendah pada perlakuan ransum buatan yaitu $0,26 \%$ dan nilai standar deviasi tertinggi pada perlakuan ransum komersial yaitu $0,31 \%$ dan nilai koefisien keragaman tertinggi pada ransum buatan $2,57 \%$ dan terendah ransum komersial 1,14\%. Namun demikian perbedaan nilai SD dan KK antara ransum buatan dan ransum komersial memiliki selisih nilai yang jauh sehingga dapat dikatakan bahwa pemberian ransum buatan maupun ransum komersial menghasilkan keragaman yang berbeda pada berat lemak abdominal ayam broiler.

Hasil analisis (t-test) menunjukkan bahwa perbedaan berat lemak abdominal antara kedua perlakuan ini berbeda sangat nyata $(p<0,01)$. Dengan kata lain kedua perlakuan ini tidak memiliki kualitas yang sama. Hal ini berarti semua bahan baku lokal yang diberikan memiliki nilai lemak yang baik. Seiring dengan pendapat (Zulkarnaen, 2013) menyatakan peningkatan protein sebanyak $1 \%$ dalam ransum akan mengurangi kandungan lemak dalam karkas sampai $0,5 \%$ dan akan mengurangi kandungan lemak abdomen antara $0,1 \%-0,15 \%$.

\section{Simpulan}

Pemberian ransum buatan dari bahan baku lokal mampu menghasilkan nilai berat potong sebesar 1761,06 gr/ekor dan berat karkas 1573,37 gr/ekor dan tidak berbeda dengan ransum komersial sebesar 1772,94 gr/ekor dan 1584,03 gr/ekor. Pemberian ransum komersil menghasilkan berat lemak abdominal 27,36 gram/ekor lebih tinggi dibanding ransum buatan 9,95 gr/ekor, sehingga dapat dikatakan bahwa konsumsi ransum komersil lebih efektif diubah makanan menjadi lemak.

\section{Pustaka}

Anita, S., Widagdo, W., 2011. Budidaya Ayam Broiler 28 hari panen. Pinang Merah Publisher: Yogyakarta.

Fadilah, R., 2013. Beternak Ayam Broiler. AgroMedia Pustaka: Jakarta.

Soematri, Muhidin, 2006. Teknik Analisis Dalam Penelitian Percobaan. Tarsito: Bandung.

Sudiyono, A., 2002. Pemasaran Pertanian. Universitas Muhamadya: Malang. Sugiyono, 2000. Statistik untuk Penelitian (Cetakan ke 3). Alfabeta: Bandung. Supriyadi, M., 2011. Beternak Itik Hibrida Unggul. Penebar Swadaya: Jakarta. Wahju, J., 2004. Ilmu Nutrisi. Gadja Mada University Press: Yogyakarta.

Zulkarnaen, D., 2013. Lebih Sukses dan Untung Beternak Ayam Broiler. Dafa Publishing: Surabaya. 